\title{
Axiological assumptions in Qohelet: A historical-philosophical clarification
}

Author:
Jaco W. Gericke'
Affiliation:
'School of Basic Sciences,
Faculty of Humanties,
North-West University,
South Africa
Correspondence to:
Jaco Gericke
Email:
21609268@nwu.ac.za
Postal address:
Vidi Flats 606, De Beer Street
616, Wonderboom South,
Pretoria 0084, South Africa
Dates:
Received: 11 Nov. 2010
Accepted: 27 Sept. 2011
Published: 23 Feb. 2012
How to cite this article:
Gericke, J.W., 2012,
'Axiological assumptions
in Qohelet: A historical-
Vhilosophical clarification',
515, 6 pages. http://dx.doi.
org/10.4102/ve.v33i1.515

(C) 2012. The Authors. Licensee: AOSIS OpenJournals. This work is licensed under the Creative Commons Attribution License.
The article has as its working hypothesis the proposal that from a philosophical perspective, the Book of Qohelet can be read as having axiology rather than epistemology or existential issues as its core concern. In order to justify this claim, Qohelet's insight regarding what is good is viewed against the backdrop of various categories in value theory. This leads to the conclusion that the author's central message was not about meaninglessness or mystery but about worthlessness.

\section{Introduction}

The Book of Qohelet (or Ecclesiastes) is the closest the Old Testament comes to approximate philosophical literature. Readings of the book from a philosophical perspective have suggested that Qohelet was concerned with existentialist issues (in general) and epistemological matters (in particular) (see Fox 1989). In this article a rather different philosophical take on the book's main thesis is offered. It involves reading Qohelet in the context of value theory, which encompasses a range of approaches to understanding how, why, and to what degree humans do and should value things, whether the object of value is a person, idea, or anything else (see Schroeder 2008:n.p.).

According to Schroeder (2008:n.p.), the concept of value theory has been used in a number of different ways:

- In its broadest sense, 'value theory' encompasses all branches of moral philosophy, social and political philosophy, aesthetics, and sometimes feminist philosophy and the philosophy of religion, in other words, any area of philosophy that encompasses some 'evaluative' aspect.

- In its narrowest sense, 'value theory' is used for a relatively narrow area of normative ethical theory of particular concern to consequentialists. Here 'value theory' is roughly synonymous with 'axiology' and is primarily concerned with classifying which things are good, and how good they are.

- In a third sense, 'value theory' designates the area of moral philosophy that is concerned with theoretical questions about value and goodness of all varieties, the theory of value. The theory of value encompasses axiology but also includes many other questions about the nature of value and its relation to other moral categories.

The latter sense will be adopted in the discussion. The chosen method of inquiry is a descriptive type of axiological analysis that seeks to understand the taken-for granted folk-theory of value underlying the discourse of the Book of Qohelet. The aim is to discern Qohelet's own axiological assumptions without reading anachronistic philosophical ideas into the ancient text. The hypothesis to be justified in doing so is that a major concern for Qohelet was the absence of absolute value. As clarified from the perspective of categories in value theory, this understanding of the book's main thesis represents a possible and novel solution to the old riddle regarding the precise nature of Qohelet's scepticism.

\section{Axiological assumptions in Qohelet}

There is no meta-axiological reflection or systematic philosophy of value in Qohelet. Neither is there any direct Hebrew equivalent to the English word 'value' anywhere in the text. However, it is quite obvious that the 12 chapters of the book are full of judgements about what is considered to be 'good' or 'better' and, correspondingly, 'bad' or 'worse'. In fact, the Hebrew word טוט [good] features prominently in the discourse, occurring no less than 51 times. Also the word רָָ [bad] appears no less than 30 times. Given that there are only 222 verses in the book, it would seem that the implied author was definitely interested in valuing things (cf. Murphy 1992:xxix). This is evident in Qohelet's recapitulation of his objective (cf. v. 1:13).

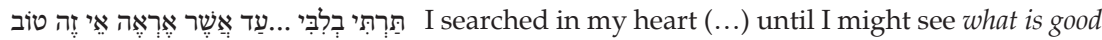

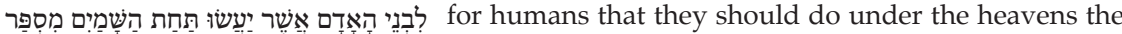
number of the days of their lives (v. 2:3 [author's own emphasis]). 
Clearly here epistemological issues are subsumed under an overarching concern with value, in other words, with what is good. Given this, we may begin our probing with some assumptions:

1. Qohelet held certain assumptions about what goodness was assumed to be.

2. Qohelet took for granted necessary and/or sufficient conditions for something to count as good.

3. Qohelet presupposed the availability of criteria for determining what is good.

4. Qohelet believed in the possibility to distinguish what is good from what is not.

If these assumptions are justified it means that underlying Qohelet's discourse is a folk-axiology (and theory of value) that can be made explicit via philosophical commentary. Applying axiological theory proper (following the outline by Schroeder 2008), it is possible to identify four grammatical forms in the value $(x=$ good) claims of the book. First of all we encounter sentences where 'good' is predicated of a mass term. Such sentences constitute a central part of traditional axiology. These are value claims pertaining to different kinds of things of which value is predicated (like pleasure, knowledge and money). For example:

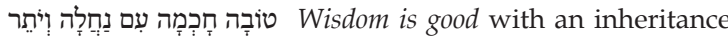

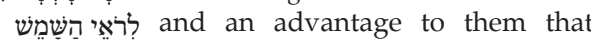
see the sun (v. 7:11 [author's own emphasis]).

Secondly, some sentences make claims about what one may call goodness simpliciter; this is the kind of goodness appealed to by traditional utilitarianism which is the default axiological assumption in many Old Testament texts, for instance:

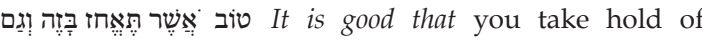

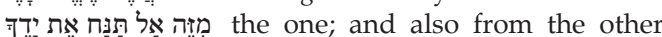
withdraw not your hand (v. 7:18 [author's own emphasis]).

Thirdly there are sentences which can be called good for sentences in which the subject following 'for' is a person so that we usually take them to be claims about welfare or well-being:

For who knows what is good for

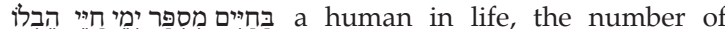

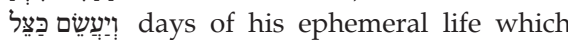
he spends like a shadow? (v. 6:12 [author's own emphasis]).

Fourthly we find sentences that involve the attributive uses of 'good', because 'good' functions as a predicate modifier, rather than as a predicate in its own right:

Good is a name more than good oil (v. 7:1 [author's own emphasis]).

According to Schroeder (2008), a theory of value begins with questions or assumptions about how these four kinds of axiological claims are related to one another. Our historical and descriptive axiology of Qohelet has something similar in view by seeking to locate Qohelet's folk-theory of value within the standard philosophical (axiological) categories.

\section{Realism and naturalism}

What was Qohelet doing when he ascribed value to some person, action, or state of affairs? Answering this question involves explaining the meaning of evaluative judgements for Qohelet. We may therefore ask what the word 'good' signified in Qohelet. Consider the following example:

For there is not a just man upon

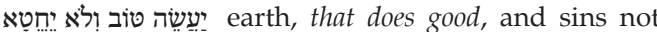
(v. 7:20 [author's own emphasis]).

Here the good is associated with moral behaviour. From a metaphysical perspective we may note that Qohelet's assumptions were not anti-realist. He assumed that sentences such as ' $x$ is good' attributed property to an object. He did not hold that evaluations merely express the speaker's feelings and attitudes. Qohelet did not assume that his claim that something was good was merely his own approval thereof as though opposing viewpoints could have equal merit. Similarly, evaluations were not assumed to be merely prescriptions (commands).

In other words, assuming that actions are good was not simply Qohelet's way of telling readers that they should be good. Evaluative judgements were not understood only as emotive or prescriptive - they were assumed to be descriptive judgements. In short, Qohelet was neither an emotivist nor a prescriptivist. Qohelet was a value realist in as much as he assumed that evaluative statements purport to represent facts about the world. This is evident when we consider negative evaluations as well. Consider the following statement:

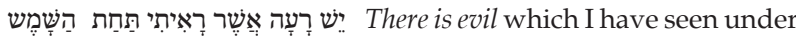

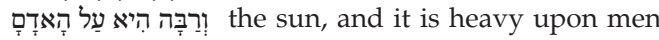
(v. 6:1 [author's own emphasis]).

From Qohelet's perspective, also negative axiological assessments of a particular state of affairs were supposed to say something about what is wrong with the world as it is and not merely about his experience thereof. When Qohelet denied the value of something, he attributed to it the property of being bad or evil. When Qohelet said that $\mathrm{x}$ is bad or evil he was (aiming to) state a fact about reality as it is, rather than a fact about himself. This statement, viz., ' $x$ is bad or evil' was assumed to be true if and only if $x$ lacked the property of goodness. Both good and evil were therefore believed to be properties that were ascribed to an object in which case the sentence would be true only if the object did possess the attributed property.

Whilst value realists have in common the assumption that attributing value to an object or person involves ascribing a property - goodness - to that person or thing, they disagree about the nature of the property attributed. As a result, they can be divided into two camps: (1) non-naturalists, and (2) naturalists. Which was Qohelet?

Firstly, it is clear that Qohelet was not a non-naturalist because he did not assume that any attempt to identify 'good' with a natural property (such as producing pleasure, 
or being desired) commits a 'naturalistic fallacy'. 'Goodness' was not a simple 'non-natural' property for him (i.e. not discoverable or quantifiable by empirical investigation.) This reading rules out the possibility that Qohelet was an intuitionist in his axiological epistemology because he did not assume that value-properties not discovered by rational and empirical investigation must be known by an intuition of some sort. To be sure, Qohelet often 'spoke' to his heart (i.e. thought), but he was always concerned with empirical states of affairs.

Thus the converse is readily apparent: Qohelet's folkaxiology was naturalistic in that he identified goodness with some natural property or properties. He associated value or goodness with properties that he believed could be discovered by empirical means, hence his empirical investigations (see Fox 1989) and his conclusion:

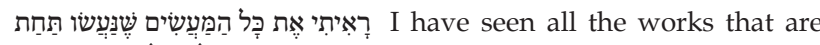

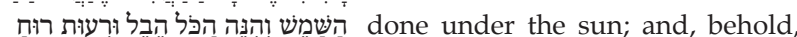
all is vapour and a striving after wind (v. 1:14).

The rudimentary form of value naturalism nascent in Qohelet's axiological assumptions also assumes that an object is good if and only if a person has a positive interest in that object. This version of naturalism has parallels to a modern version of the theory which identifies goodness with what is desired by an observer in ideal conditions, in other words, with a god's eye view.

\section{Subjectivism}

Contrary to what one might expect, whilst Qohelet was a realist and a naturalist in his axiological assumptions, he was not an objectivist. Qohelet characterised value in terms of the tastes of individual sentient creatures and by implication affirmed to some extent that the kind of goodness he was concerned with depended on what was desired or valued by people. Consider the following example:

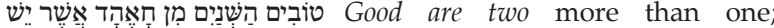

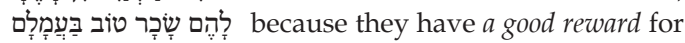 their labour (v. 4:9 [author's own emphasis]).}

Like all subjectivists Qohelet had a hard time thinking of states of affairs as good apart from any pleasure or satisfaction they bring. To be sure, there might be some objectivist strands in his deconstructed discourse, yet the overriding flavour is subjectivism. Good things were not assumed to make life better independently of how much they are desired or enjoyed, and their absence diminished their value if this became a source of regret. So contra objectivist theories of value, Qohelet did not hold that certain things could be valuable independently of their impact on consciousness states. If something is 'bad' for humans it was held to be bad - period. For Qohelet, states of affairs are what they are and whilst this seems like objectivism, the latter may be a euphemism for divine subjectivism:

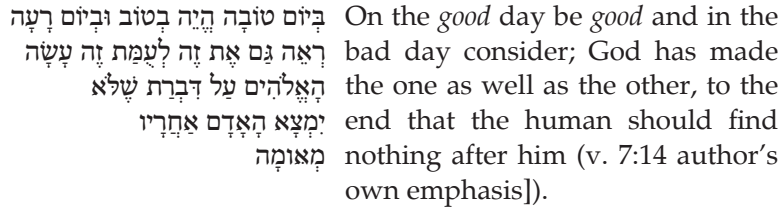

Surely what is good and bad here is held to be so because it is experienced as such from someone's perspective. A good or bad day is not objectively so from everyone's perspective. Qohelet's foreignness to value objectivism is already evident in his denial of perfection. Axiology perfectionism contains an objectivist theory of value because it assumes that goodness depends on the actualisation or perfection of human nature. Qohelet did not believe such a thing to be possible - humans seemed crazy by default, even if not by design (v. 7:29). There is also the idea of inherent imperfection in the view that some things are by nature crooked:

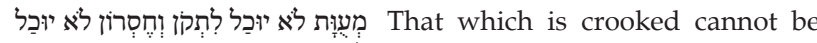

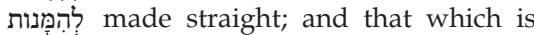

Of course, contra Aristotle's rationalist version of the theory of perfection, Qohelet did not assume that fulfilling the function of a human being involved the exercise and perfection of one's rational capacities. For Qohelet, reason seemed vulnerable, if not useless, without power, luck and immortality. The 'good life' was not assumed to be identical to the attainment of virtue or excellence in reasoning because it guaranteed nothing in terms of value. In fact, those living good lives sometimes suffer from appalling evil and thus actually have bad lives:

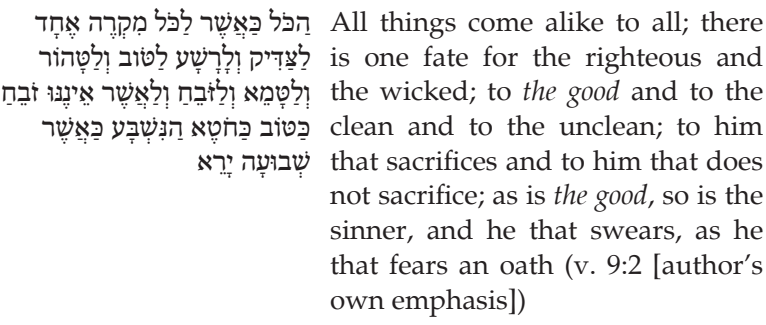

Qohelet thus presupposed a subjectivist theory of value. That this is true for the bulk of his axiological assumptions (which may contain traces of objectivism where 'ends' are in view) can be seen in the way Qohelet presupposed that what is called good is such because of the subjective states of agents. When Qohelet began his quest to determine what was good he also subscribed to a proto-utilitarian theory of value with elements of hedonism. This is interesting, if only for the reason that the most popular use of the concept of goodness in the Old Testament is in fact utilitarian (Johag 1986:304) Right up to the end, Qohelet recommends sensual pleasures, albeit tempered with quasi-Epicurean moderation and quasi-Stoic acceptance to changing circumstances.

In Qohelet's subjectivism, however, there is no trace of any so-called simple point of view theory. In other words, what 
was held to be good simpliciter did not differ from what was held to be good from the perspective of the 'I' in Qohelet. Being good simpliciter was not limited to a more general point of view, the point of view of the deity. Qohelet did not complicate what is good for and good simpliciter by ascribing them to two or more sources. What is good was assumed to be so for everyone in a similar situation (see Smith 2003:576-598). Qohelet's use of the concept of goodness thus makes no sense if one takes away the perspectives of the deity and its human creatures. Goodness is real, but it is always relative to agents:

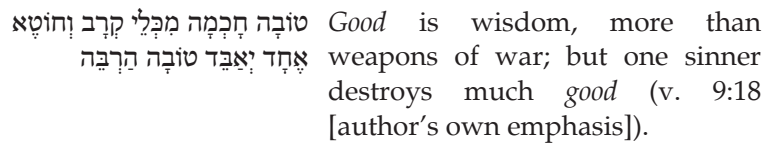

Clearly, the concept of the 'good' here means 'good for someone'. Qohelet does not seem to understand good simpliciter in terms of attributive good because the state of affairs described involves an elliptical good for sentence with some agent in mind for whom it is good.

\section{Extrinsic value and instrumental goods}

An important distinction in value theory related to the aformentioned information is between intrinsic and extrinsic value (see Zimmerman 2001, 2010). An object or state of affairs is 'intrinsically' valuable if it is good simply because of its internal nature. It does not derive its value from anything else. We have already seen this is not the case in Qohelet who seems to know nothing of goods without anyone to enjoy them. For Qohelet, value was assumed to be extrinsic in nature as its worth was assumed to be derivative from something else.

Of course, intrinsic value can also be contrasted with instrumental value. This important distinction in value theory concerns the difference between things valued as means (instrumental goods) and things valued as ends (final goods). The distinction is often called the means or ends distinction. An object, experience or state of affairs is 'instrumentally' valuable if it serves as a means to ones ends. In Qohelet's 'experiment' in chapter 2 the whole idea of instrumental value is rejected altogether:

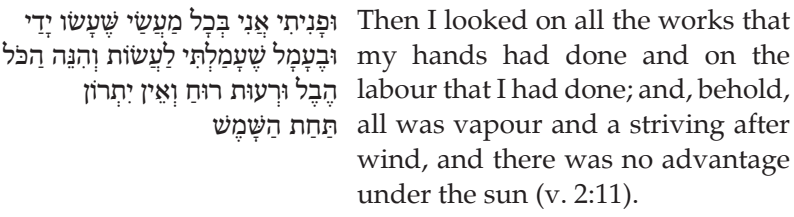

Thus for the Qohelet of chapter 2 at least (he often contradicts himself), what was assumed to be valuable would be such only if one could obtain something more by means of it. Yet he finds no advantage in positive emotional states that have no instrumental value at all:

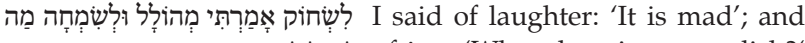
זה עשָׁה of joy: 'What does it accomplish?' (v. 2:2).

Later Qohelet does assign relative value to the pleasures he previously considered empty:

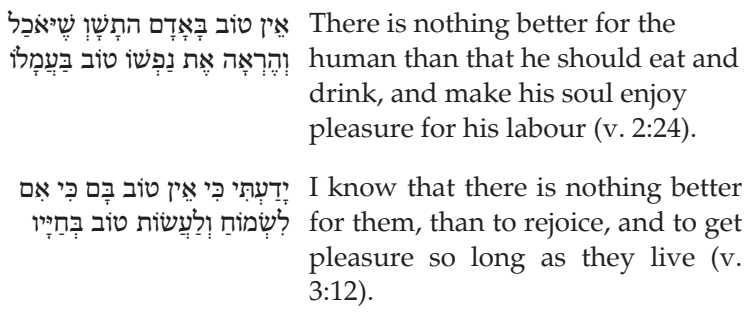

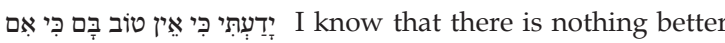

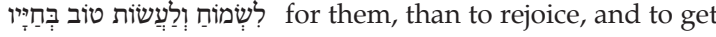
pleasure so long as they live ( $\mathrm{v}$. 3:12).

In both these early examples of recommended valuable actions, there is the reminder that engaging in pleasurable activities is not always a free decision; rather, the ability to enjoy is a gift from the deity. Thus in the book there is an inconsistency between texts that seem to value happiness and pleasure as apparently of intrinsic end-worth and those denying that these same goods have any ultimate value. This leads to the question of the relation between the instrumental or final values and extrinsicand intrinsic values in Qohelet. Instrumental goods for Qohelet were assumed to be extrinsically valuable, because their goodness derived from the good things that they promote. As we saw; however, this distinction did not always hold: in some texts Qohelet assumed that happiness was an extrinsic good that could sometimes become the final end of human action. Thus it may be that whilst Qohelet at first claimed to know that nothing is intrinsically good he later ascribes to instrumental goods, like pleasure, the property of being final goods. These may be void of ultimate value but they are the best one can do in this life. Qohelet's axiology thus exhibits hedonistic tendencies, but these are tempered by limitations based on human fate and divine fiat.

In value-theory, instrumental value is also sometimes contrasted with 'constitutive' value. The idea behind this distinction is that instrumental values lead causally to intrinsic values, whilst constitutive values amount to intrinsic values. For example, for Qohelet eating and drinking ordinarily causally result in experiencing pleasure, whereas experiencing pleasure can at times be seen to constitute, without causing, one's being happy (or not). For Qohelet's purposes this distinction is not very important and constitutive values were thought, along with instrumental values, as mistakenly trying to get something of intrinsic value. He did; however, assume a distinction between conditional values and unconditional values. A conditional value is something valuable in some circumstances whereas an unconditional value is always valuable. For Qohelet, most values are conditional because he could imagine circumstances in which it would be bad for someone to possess it, such as when it would be the cause for misery or used for unfair or evil ends.

\section{Monism and relative versus absolute value}

One of the oldest questions in the theory of value is that of whether there is more than one fundamental (intrinsic) value 
(see Mason 2011). Monists deny this and pluralists affirm it. As Qohelet denied the existence of actual intrinsic value the question is whether he was denying the reality of one or of more than one fundamental intrinsic value (Schroeder 2008:n.p.). First there is an ontological explanatory issue that we need to look at. If wisdom and knowledge were both of (relative) value for Qohelet, the question remains why this should be so. If this question had an answer it must be because there was a further, more basic value under which the explanation subsumes both wisdom and knowledge.

Here we encounter an important axiological concept in Qoheleth: 'יתרו:' [advantage]. It is found right at the beginning in the summary statement of Qohelet's wisdom:

What profit has a human in all his ת תחת השטמש the sun? (v. 1:3).

The root יתר [to gain] appears 15 times in Qohelet (Murphy 1992:xxix). The popular translation with 'profit' is problematic because whilst Qohelet suggests it is often missing in toil (vv. $2: 11 ; 3: 9)$, he also finds it in this and other activities or things (such as one's portion). According to Fox (1989:60), , ת:? is therefore better understood if we take it to refer either to relative 'advantage' (two things are compared) or to adequate gain (when used absolutely). Both cases have in common a concern with value. When referring to advantage we are dealing with relative value and in the context of enduring gain it denotes absolute value for Qohelet.

As 'relative value' or 'advantage', , :ְּ? (twice);3:19;5:8;6:8, 11;7:11,12;10:10. Here the concept of gain takes its form from the comparison of two phenomena: one thing is superior to something else. The object of comparison with which the subject is compared is often vague, especially when Qohelet is denying the existence of an advantage. These comparisons are both explicit (vv. 2:13; 3:19; 6:18) and implicit (v. 10:10). What is of advantage include silence over speech (v. 6:11), wisdom over wealth (vv. 7:11, 12) and skill over power (v. 10:10).

As 'absolute value' or 'enduring gain' תִּר:? is opposed to the temporality of one's 'portion' and concerns value adequacy and returns. This involves not only toil's material compensations but also whether it is ultimately worth one's while. Several contexts are involved. In verse 1:3 we find not so much a categorical denial of enduring gain as the idea that labouring processes do not add up in value. In verse 2:11 the idea is that pleasure, whilst having a positive value offers no enduring gain and do not offer a reasonable return for straining to achieve it. In verse 3:9 toil is held to offer little gain in as much as humans cannot make an impact on the divinely ordained course of events. According to verse 5:15, nothing can be adequate repayment for a struggle whose rewards must be left behind whilst in verse 10:11 the timing in using knowledge determines whether there is any gain at all.

Qohelet's use of the concept of ית:? supports the thesis that his primary concern lay with axiological matters. However, as there is no תִּר that is lasting, Qohelet's negative theory is a form of pessimistic monism and based on the assumption that whilst there could only be one intrinsic absolute value, it is in fact lacking, in other words there is no actual opposite of הָבֶל Because there is only one intrinsic value, the state of affairs that is better is the one that has more of the basic intrinsic value, which is ת: However, because some things that were assumed by Qohelet intuitively having some relative value (such as wisdom) do not, in fact, always lead to תִּ, Qohelet was committed to paradoxically deny that these things are valuable in any absolute sense. This accounts for many of his contradictions.

\section{Good versus right}

What is the relationship between the theory of right action and the theory of value in Qohelet? The answer depends on the ethical theory underlying the particular axiological assumption in any given text. In some places Qohelet seems to presuppose a form of classical utilitarianism that aims to account for right action in terms of the promotion of human good. In this respect, Qohelet's utilitarian view requires an account of human good in order to specify just what sort of good consequences must be maximised. Such a classical type of utilitarianism in Qohelet thus holds that morally right actions are simply those that produce the maximum balance of pleasure over pain. By contrast, in some cases we find deontological perspectives which do not assume right action in terms of the promotion of good.

In this regard, it will be remembered that throughout reception history, it has been remarked that the book of Qohelet is not the most ethically orthodox of biblical texts. Consider the following warning against overzealous piety:

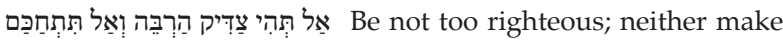

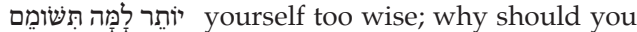
destroy yourself? (v. 7:16).

The shock value of texts like these is further enhanced by the denial that the good have a good life and that evildoers suffer because of their evil (see v. 9:2) From this it is clear that Qohelet's crisis is that there is no necessary connection between what is good (i.e. valuable for humans) and right (i.e. moral). Of course, also here the book's assumptions are not coherent. In his deontological mood Qohelet implied that it is wrong to act like a fool no matter what the value of the consequences might be. Whereas the utilitarian Qohelet views right action in terms of the promotion of goodness, the deontologist in him holds that certain moral actions are more important than increasing the amount of value in the world. This is sometimes expressed by saying that deontology places what is right prior to what is good (e.g. vv.7:1-3).

For Qohelet, because humans cannot know the future or control the world, what today goes under the name of classical consequentialism would have been out of the question in his axiology. Qohelet's crisis was that when one does something good it does not mean that it is for the best. Like all nonconsequentialists, Qohelet assumed that actions are better if they are supported by some sort of reason for behaving in 
a certain way. Consider chapter 5's cultic advice or chapter 8 's political counsel. So the evaluative status of actions is understood in terms of its deontic status; not conversely. This explains the concern with divine judgement in the book which balances the more radical claims (cf. v. 12:1). These are reasons why one should not, given uncertainty and injustice, commit evil. For Qohelet, consequentialism ignores the unforeseeable nature of the future.

However, universalisable egoism is also not the best teleological theory with which to classify the axiologicalmoral assumptions in Qohelet's thought. The idea that each agent ought to always to do whatever action is the best for himself is not clearly visible in the book. Qohelet may not be asking moral agents to maximise the good, but neither does egoism in Qohelet appear when he asks agents to maximise what is good for them. Hence the absence of the modern teleological idea that the deontic is to be explained in terms of the evaluative (see also Portmore 2005:95-113)

In contrast to teleological theories, which seek to account for deontic categories in terms of evaluative ones, Qohelet seems to have assumed what is called a Fitting Attitudes account in that he takes it for granted that what is 'good' is also what is 'desirable'. However, Qohelet believed that humans cannot find this out (vv. 6:12;11:5) and the slogan is not by itself very helpful. Perhaps the best way to articulate Qohelet's implied dilemma with consequentialism is in terms of so-called agentcentred constraints (see Louise 2004:518-536).

According to this view, each agent ought always to do what has a chance to bring about the results that are best relative to them. One of the motivations for thinking that there must be such a thing as agent-relative value in the book's contradictory contents comes from strands of Fitting Attitudes assumptions in the author's folk-theory of value. If the good was what ought to be desired, then there were two kinds of good; what ought to be desired by everyone as 'agent-neutral' good, and what ought to be desired by a particular person as the good relative to that person (see also Louise 2004:518-536). As there is no necessary connection between these two, Qohelet is an axiological pessimist advising moral pragmatism.

\section{Relevance of the axiological hypothesis}

If, as this article has argued, axiology rather than metaphysics, epistemology or ethics (or existentialist concerns) is the main focus of Qohelet, it means that mainstream scholarly views regarding the author's central claim could be wrong. Let us consider the metaphor in verse 1:2:

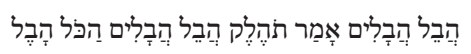

Contra Fox (1989), the core meaning of this phrase need not be understood to denote absurdity. That reading loses much of its explanatory power when we consider the likelihood of an anachronistic existentialist projection onto an ancient text. Neither does הָבְ connote 'mystery' or 'incomprehensibility', both of which tend to be concepts posited by readers who want to tone down the harshness of Qohelet's sweeping statements (see Murphy 1992:xxix). Perhaps Qohelet was in fact making a claim about the value of things, as opposed to denying their meaning or comprehensibility. From this perspective, it is possible that the metaphor of vapour connoted 'worthlessness.'

Translating הְָב as 'worthlessness', of course, is not novel so I cannot take credit for it. It has a long record in the book's Christian reception history. However, there is a difference between the present reading and those of yesteryear. In my view, Qohelet does not teach worthlessness in a Platonist or monastic sense where the world and its phenomena are evaluated as being of little value in comparison to a transcendent spirit world (the traditional Christian associative meaning of 'worthlessness'). Rather, Qohelet teaches a form of active nihilism (cf. Nietzsche) that constructs reality through an economic metaphor and in doing so find it lacking any absolute value.

\section{Conclusion}

Reading Qohelet along the lines followed by this article shows that an informative philosophical sub-discipline to which we may look to in order to clarify the author's claims is axiology. The author's folk-axiological assumptions were for the most part realist, naturalist and subjectivist. The 'good' was an extrinsic property for Qohelet and he denied the reality of intrinsic and instrumental goodness that could constitute any absolute value. The metaphysics underlying such an axiology is a combination of monism and nihilism whilst its moral presuppositions advise us to create pockets of value through pleasure and wisdom wherever reasonably possible. In the end it is possible that the main idea of the book is therefore not life's meaninglessness or incomprehensibility but its ultimate worthlessness.

\section{Acknowledgements Competing interests}

The author declares that he has no financial or personal relationship(s) which may have inappropriately influenced him in writing this paper.

\section{References}

Fox, M.V., 1989, Qohelet and his Contradictions, JSOT Supplement Series, JSOT Press, Sheffield.

Johag, H., 1986, s.v. בְiv, in G.J. Botterweck \& H. Ringgren (eds.), Theological Dictionary of the Old Testament, vol. V, pp. 296-317, William B. Eerdmans, Grand Rapids.

Louise, J., 2004, 'Relativity of Value and the Consequentialist Umbrella', Philosophical Quarterly 54, 518-536.

Mason, E., 2011, 'Value Pluralism', The Stanford Encyclopedia of Philosophy (Spring 2011 Edition), E.N. Zalta (ed.), viewed 18 March 2011, from http://plato.stanford. edu/archives/spr2011/entries/value-pluralism/

Murphy, R., 1992, Ecclesiastes, (World Biblical Commentary Series), Thomas Nelson Publishers, Nashville.

Portmore, D., 2005, 'Combining Teleological Ethics with Evaluator Relativism: A Promising Result', Pacific Philosophical Quarterly 86, 95-113.

Schroeder, M., 2008, 'Value Theory', The Stanford Encyclopedia of Philosophy (Fall 2008 Edition), E.N. Zalta (ed.), viewed 04 April 2011, from http://plato.stanford. edu/archives/fall2008/entries/value-theory/

Smith, M., 2003, 'Neutral and Relative Value After Moore', Ethics 113, 576-598.

Zimmerman, M.J., 2001, The Nature of Intrinsic Value, Rowman and Littlefield, Lanham.

Zimmerman, M.J., 2010, Intrinsic vs. Extrinsic Value', The Stanford Encyclopedia of Philosophy (Winter 2010 Edition), E.N. Zalta (ed.), viewed 21 March 2011, from $\mathrm{http}: / /$ plato.stanford.edu/archives/win2010/entries/value-intrinsic-extrinsic/ 